\title{
Analisis Keterampilan Menulis Puisi dengan Menggunakan Kolaborasi Metode SSCS dan Media Audio Visual
}

\author{
Lisa Anggriani, Sutrimah, Cahyo Hasanudin \\ Fakultas Pendidikan Bahasa dan Seni, IKIP PGRI Bojonegoro \\ lisaanggriani1998@gmail.com
}

Received: 23 Februari 2020; Revised: 27 April 2020; Accepted: 28 April 2020

DOI: http://dx.doi.org/10.37905/aksara.6.2.213-224.2020

\begin{abstract}
Abstrak
Penelitian ini bertujuan untuk mengetahui puisi yang ditulis oleh siswa kelas X 2 Agama MA ABUDARRIN Kendal Bojonegoro, Indonesia pada pembelajaran kolaborasi metode SSCS dan media audio visual. Penelitian ini adalah penelitian kualitatif dengan menggunakan pendekatan deskriptif kualitatif dengan jumlah subjek 34 siswa. Dari 34 siswa selanjutnya peneliti mengambil 5 siswa untuk diwawancarai dengan alasan mereka memiliki kemampuan menulis puisi yang baik sesuai indikator. Teknik pengumpulan data menggunakan metode tes, wawancara, observasi, dan dokumentasi. Data divalidasi dengan menggunakan triangulasi sumber dan triangulasi metode. Teknik analisis data menggunakan metode content analysis dengan dimulai dari 1) reduksi data, 2) penyajian data, dan 3) penarikan simpulan/verifikasi. Hasil penelitian menunjukkan bahwa puisi yang ditulis oleh siswa kelas X 2 Agama MA ABUDARRIN Kendal Bojonegoro, Indonesia sudah mengacu pada struktur puisi menurut Waluyo. Simpulan pada penelitian ini adalah metode SSCS yang berbantukan media audio visual sangat tepat diterapkan pada pembelajaran. Metode SSCS dan media audio visual dapat membuat siswa untuk berfikir kreatif serta dapat menunangkan ide-idenya kedalam bentuk puisi.
\end{abstract}

\section{Kata Kunci}

Metode SSCS, media audio visual, puisi.

\section{PENDAHULUAN}

Pembelajaran bahasa Indonesia di sekolah melatih empat aspek keterampilan berbahasa yakni keterampilan menyimak, keterampilan berbicara, keterampilan membaca, dan keterampilan menulis (Julaeha, 2018). Aspek keterampilan menulis dapat dilihat pada materi kelas $\mathrm{X}$ tentang menulis laporan hasil observasi, menulis teks eksposisi, menulis anekdot, menulis cerpen, menulis teks negosiasi, menulis teks debat, menulis teks biografi, dan menulis puisi (Suherli, Suryaman, Septiaji, dan Istiqomah, 2017).

Pembelajaran menulis puisi di SMA pada Kurikulum 2013 terdapat pada kompetensi dasar (KD) 4.17 yang berbunyi menulis puisi dengan memerhatikan unsur pembangunnya (tema, diksi, gaya bahasa, imaji, struktur, pewajahan). Menurut Laeli, Wagiran, dan Suseno (2014) keterampilan menulis puisi merupakan keterampilan yang belum dikuasai oleh siswa, karena keterampilan menulis puisi siswa masih rendah. Siswa sulit dalam menentukan tema dan kesulitan dalam mencari bahasa yang tepat untuk mengapresiasikan apa yang dipikirkannya. Sedangkan menurut Kibtiyah dan Abbas (2014) ada faktor lain yang mempengaruhi yaitu cara mengajar guru yang menggunakan 
metode konvensional, sehingga proses kegiatan belajar mengajar terkesan membosankan dan siswa hanya menerima pelajaran secara pasif.

Berpijak dari hasil wawancara dan observasi pada pembelajaran bahasa Indonesia di kelas ditemukan beberapa kendala yang dialami oleh siswa ketika menulis puisi. Kegiatan menulis puisi merupakan kegiatan yang sulit dilakukan, karena siswa mengalami kesulitan dalam menuangkan ide-idenya kedalam bentuk puisi. Siswa juga kurang tertarik dalam pembelajaran menulis puisi karena guru selama ini hanya menggunakan metode konvensioanal (ceramah) yang membuat proses pembelajaran menjadi menjenuhkan dan monoton karena guru tidak mencoba menggunakan metode atau media pembelajaran yang dapat merangsang ide kreatif siswa untuk menulis puisi.

Berdasarkan permasalahan yang dialami siswa mengenai kesulitan dalam pembelajaran menulis puisi, harus ada upaya guru dalam menciptakan metode pembelajaran yang inovatif. Metode yang dapat diterapkan dalam proses pembelajaran menulis puisi yaitu metode SSCS (Search, Solve, Create, and Share).

Metode SSCS adalah metode pembelajaran yang berbasis pemecahan masalah atau problem solving (Maulana, Wancik, dan Sofia 2014). Menurut Astuti, Suweken, dan Waluyo (2018) metode SSCS merupakan metode pembelajaran yang menekankan pada pendekatan saintifik atau berpikir secara logis. Menurut Agustin, Fitraini, Rahmi, dan Fitri (2018) metode SSCS adalah metode pembelajaran yang mengajak siswa untuk berperan aktif dalam kegiatan pembelajaran. Metode SSCS merupakan metode yang mengajarkan suatu proses pemecahan masalah (Lartson dalam Hatari, Widiyatmoko, dan Parmin 2016).

Keunggulan metode pembelajaran SSCS (Search, Solve, Create, and Share) adalah mampu meningkatkan kecakapan siswa dalam hal bertanya serta siswa mampu bertanggung jawab terhadap cara belajar (Deli, 2015). Keunggulan metode SSCS yaitu memberikan kesempatan kepada siswa untuk mengasah kemampuan memecahkan masalah (Pizzini dalam Rahmawati, Junaedi, dan Kurniasih, 2013). Menurut Sarastini, Rasana, dan Sulastri (2014) keunggulan metode SSCS adalah siswa terlibat langsung dalam mencari solusi dari permasalahan sehingga dapat menyelesaikan masalah.

Menurut Rahmawati dan Sugianto (2016) metode SSCS terdiri dari empat fase yakni fase search, solve, create, and share. Fase share merupakan fase yang melibatkan siswa untuk mengidentifikasi masalah. Fase solve mengharuskan siswa untuk mengidentifikasi solusi dan menyelidiki masalah dengan menerapkan rencana. Fase create mengharuskan siswa menunjukan data mereka dengan menyiapkan cara untuk mengkomunikasikan masalah, metode, hasil, dan kesimpulan. Fase share merupakan langkah terakhir, dimana siswa mensosialisasikan solusi dari pemecahan masalah.

Metode pembelajaran SSCS bisa menjadi alternatif dalam mengatasi kesulitan siswa dalam menulis puisi. Pembelajaran menulis puisi menuntut siswa untuk memecahkan masalah dengan mencari ide-ide serta menuangkan ide tersebut kedalam bentuk tulisan menjadi puisi. Metode SSCS pada tahap search siswa diharuskan untuk mencari sebuah ide dalam menulis puisi. Ide-ide pada puisi tersebut dapat dicari dengan bantuan media yang tepat. Salah satu media yang dapat membantu dalam tahap search adalah media audio visual berbentuk video.

Media menurut Hasanudin (2017) adalah segala sesuatu yang dapat digunakan untuk menyalurkan pesan dari pengirim ke penerima sehingga dapat merangsang pikiran, perasaan, perhatian, dan minat siswa sedemikan rupa, sehingga proses belajar terjadi. 
Media audio visual merupakan media yang terdiri dari segi penglihatan dan pendengaran, yang dapat membantu siswa dalam mendapatkan pengetahuan (Syarwah, Fauziddin, dan Hidayat 2019). Pengetahuan memiliki peran dalam pembentukan perilaku (Simon dalam Retnowati, dkk., 2018). Menurut Sulfemi (2019) media audio visual adalah sebuah alat yang digunakan untuk menunjang proses kegiatan belajar yang berbentuk audio dan visual. Media audio visual merupakan bentuk dari multimedia (Hernawati, 2018).

Manfaat dari media audio visual yaitu bisa membantu guru dalam menyampaikan materi pembelajaran dan digunakan untuk merangsang imajinasi siswa, sehingga siswa dapat menuangkan idenya kedalam sebuah rangkaian kata-kata yang indah (Hermawan, 2017: 40). Diharapkan dalam pembelajaran menulis puisi berbantukan media audiovisual dapat membantu siswa dalam menciptakan ide (Nurfaedah, 2019).

Penelitian yang dilakukan oleh Hidayah, Darmuki, dan Hasanudin (2019) mengenai keterampilan menulis puisi dengan menggunakan metode quantum learning dan media video dapat meningkatkan aspek keterampilan menulis puisi. Sedangkan penelitian yang dilakukan Periartawan, Japa, dan Widiana (2014) mengenai pengaruh positif model pembelajaran SSCS terhadap kemampuan memecahkan masalah pada mata pelajaran matematika. Penelitian yang dilakukan oleh Putri dan Widihastrini (2014) mengenai keterampilan menulis puisi menggunakan metode mind mapping dan media audiovisual dapat meningkatkan keterampilan menulis puisi siswa.

Pembelajaran menggunakan metode SSCS yang berkolaborasi dengan media audio visual diharapkan dapat meningkatkan kreativitas dan daya pikir imajinasi siswa dalam menuangkan ide-idenya dalam menulis puisi. Pengkolaborasian metode dan media ini dapat menjadi alternatif bagi guru (pendidik) dalam memunculkan kreativitas peserta didik dalam pembelajaran menulis puisi. Penelitian mengenai keterampilan menulis puisi dengan mengkolaborasikan metode SSCS dan media audio visual hingga saat ini belum ada.

\section{METODE PENELITIAN}

Penelitian ini merupakan penelitian deskriptif kualitatif. Penelitian kualitatif adalah penelitian yang dilakukan secara alamiah karena data yang dikumpulkan berdasarkan fakta yang berada di lapangan, dimana peneliti sebagai intrumen kunci, dan penelitian kualitatif lebih menekankan makna (Sugiyono, 2015). Menurut Moleong (2015) Penelitian kualitatif bukan berupa angka melainkan berupa kata dan gambar yang berisi kutipan data yang memberikan gambaran mengenai hasil laporan. Data yang diperoleh pada penelitian ini adalah bagaimana tema, diksi, rima, tipografi, dan amanat pada puisi yang ditulis oleh siswa kelas X 2 Agama MA ABUDARRIN Kendal bojonegoro, Indonesia ketika diajar menggunakan metode SSCS dan media audio visual. Subjek dalam penelitian ini yaitu seluruh siswa kelas X 2 Agama yang berjumlah 34 siswa, kemudian diambil 5 siswa yang dijadikan subjek dalam penelitian untuk diwawancarai dengan alasan kemampuan menulis puisinya bagus dan sesuai indikator.

Sumber data merupakan subjek darimana data didapat (Arikunto, 2006: 129). Sumber data dalam penelitian ini adalah siswa kelas X 2 Agama MA ABUDARRIN Kendal Bojonegoro, yang berupa hasil tes menulis puisi siswa dan wawancara dengan siswa tersebut. 
$\begin{array}{ll}\text { Volume } & : 06 \\ \text { Nomor }: & 02 \\ \text { Bulan }: & \text { Mei } \\ \text { Tahun : } & 2020 \\ \text { http://ejurnal.pps.ung.ac.id/index.php/AKSARA/index }\end{array}$

Prosedur pengumpulan data bertujuan untuk mendapatkan data yang diperlukan dalam melakukan sebuah penelitian. Prosedur pengumpulan data pada penelitin ini dilakukan dengan cara sebagai berikut.

Observasi

Observasi dalam penelitian ini dilakukan secara langsung karena untuk memperoleh gambaran yang jelas mengenai permasalahan yang sedang diteliti.

Metode Tes

Tes merupakan deretan pertanyaan yang berisi latihan yang berfungsi untuk mengukur pengetahuan dan keterampilan siswa (Mamik, 2015). Metode tes digunakan untuk mengetahui keterampilan siswa kelas X 2 Agama MA ABUDARRIN Kendal Bojonegoro dalam menulis puisi. Tes menulis ini dilakukan oleh siswa secara individu setelah diajar menggunakan metode SSCS dan media audio visual. Kemudian hasil tes dianalisis untuk mengetahui keterampilan menulis puisi siswa sesuai indikator.

Langkah-langkah yang dilakukan peneliti dalam mengumpulkan data dari tes yang dilakukan siswa yaitu 1). Siswa menyiapkan kertas untuk menulis puisi, 2). peneliti mengawasi siswa dalam menulis puisi, 3). setelah siswa selesai menyelesaikan soal tes, kemudian siswa mengumpulkan hasil tesnya kepada peneliti, 4). peneliti menganalisis hasil tes siswa.

\section{Metode Wawancara}

Penelitian ini menggunakan wawancara tak berstruktur karena wawancara tak berstruktur pada umumnya dianggap sesuai dengan sifat siswa yang lebih senang menceritakan masalahnya, serta dalam melakukan wawancara tak berstruktur lebih bersifat bebas yang akan membuat siswa tidak merasa bosan. Langkah-langkah yang akan dilakukan oleh peneliti dalam mengumpulkan data melalui wawancara, yaitu: a). menyusun pedoman wawancara tak berstruktur berupa garis besar dari permasalahan yang ingin ditanyakan, 2). wawancara dilakukan pada siswa yang sesuai indikator, 3). hasil wawancara dianalisis sehingga mendapatkan hal yang berhubungan dengan kreativitas siswa dalam menulis puisi.

Dokumentasi

Dokumentasi merupakan suatu bentuk pengumpulan data yang berupa teks atau foto yang berkenaan dengan penelitian guna untuk mencari informasi (Rukin, 2019).

Teknik anlisis data pada penlitian ini merujuk pada teori Miles and Huberman dalam Sugiyono (2015) yang meliputi tiga analisis data yang terdiri dari reduksi data, penyajian data, dan penarikan simpulan.

Reduksi data

Reduksi data merupakan proses pemilihan, pemokusan atau pemusatan terhadap suatu hal yang penting, serta merangkum data yang ada dalam bentuk catatan tertulis di lapangan selama proses penelitian berlangsung.

Reduksi data dalam penelitian ini terdiri dari 1). langkah pertama dalam mereduksi data yaitu mengoreksi pekerjaan siswa kemudian memberikan penskoran terhadap hasil pekerjaan tersebut, dan 2). langkah selanjutnya yaitu melakukan wawancara kepada subjek penelitian yang memenuhi indikator penilaian, kemudian hasil wawancara itu disusun dan disederhanakan dengan menggunakan bahasa yang baik. 


\section{Penyajian data}

Setelah melakukan reduksi data selanjutnya data diolah dan dijelaskan secara singkat dan terperinci. Tahap penyajian data dalam penelitian ini yakni a). menampilkan hasil pekerjaan siswa yang sudah diseleksi sesuai indikator, 2). menyajikan hasil wawancara pada siswa yang sesuai indikator yang telah direkam menggunakan hp.

\section{Penarikan simpulan atau verifikasi}

Peneliti membuat suatu kesimpulan awal yang masih bersifat sementara tentang menulis puisi yang ditulis siswa. Penarikan kesimpulan dalam hal ini yaitu membandingkan hasil pekerjaan siswa yaitu menulis puisi dengan hasil wawancara. Apabila hasil wawancara sama dengan data hasil tes serta terdapat bukti-bukti yang mendukung dan memperkuat data, maka kesimpulan tersebut merupakan suatu kesimpulan yang dapat dipercaya (kredibel). Simpulan inilah yang menjadi simpulan akhir dari hasil penelitian.

Validitas data atau keabsahan merupakan ketepatan antara data yang didapat pada objek penelitian dengan data yang didapat oleh peneliti (Rifai, 2012). Teknik validasi data pada penelitian ini menggunakan triangulasi sumber dan triangulasi metode. Adapun langkah yang dilakukan dalam melakukan triangulasi sumber data yaitu: melakukan perbandingan antara hasil tes dan hasil wawancara. Pada triangulasi metode peneliti menggunakan lebih dari satu metode untuk mendapat data yang sama. Adapun langkah yang dilakukan dalam melakukan triangulasi metode yaitu peneliti melakukan tes menulis puisi kemudian melakukan klarifikasi dengan hasil wawancara yang telah dilakukan. Apabila data tersebut terdapat konsistensi atau kesamaan pendapat, maka data tersebut dapat dinyatakan valid.

\section{HASIL DAN PEMBAHASAN}

\section{Hasil}

Hasil puisi yang ditulis siswa dapat ditunjukkan sebagai berikut.

Berlandasan pada teori yang dikemukakan oleh Waluyo mengenai indikator menulis puisi, berikut puisi yang ditulis siswa pada mata pelajaran bahasa Indonesia. Struktur puisi yang pertama yaitu tema. Berikut ini adalah tema puisi yang ditulis oleh siswa.

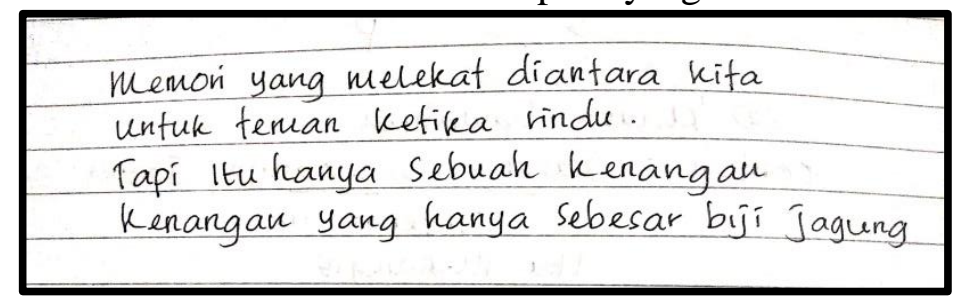

Gambar 1. Tema pada puisi

Pada lembar tes menulis puisi. Siswa membuat tema tentang kerinduaan akan sesosok ayah. Isi tema tersebut sangat menyentuh hati, dimana seorang anak yang ditinggal oleh Ayahnya karena sang Ayah telah kembali terlebih dahulu kepada sang pencipta. Berdasarkan puisi yang ditulis oleh siswa, kita dapat mengetahui bahwa siswa dapat membuat tema sesuai pedoman puisi. Ketika peneliti mengajukan pertanyaan, mengapa dia menulis puisi seperti itu. Dia menjelaskan bahwa dia merindukan sosok ayah yang sudah meninggalkannya terlebih 


$$
\begin{aligned}
& \text { Volume : } 06 \\
& \text { Nomor : } 02 \\
& \text { Bulan : Mei } \\
& \text { Tahun : } 2020 \\
& \text { http://ejurnal.pps.ung.ac.id/index.php/AKSARA/index }
\end{aligned}
$$

dahulu, dia tinggalkan ayahnya ketika ia masih duduk dibangku kelas 2 SD. Hal ini dapat dilihat pada kutipan wawancara berikut.
P : :Apakah kamu sudah memahami struktur puisi?"
S1 : "Sudah, Bu!"
$\mathrm{P} \quad$ : “Apa kamu tahu apa yang dimaksud dengan tema?"
S1 : "Saya tahu, Bu"
P : :Menggapa kamu membuat tema tentang ayah?
S1 : "Karena saya merindukan sosok ayah, Bu. Ayah saya sudah meninggal sejak saya masih duduk dibangku kelas 2 SD, kurang lebih sudah Sembilan tahun Bu" berikut.

Struktur kedua dalam puisi yaitu diksi. Diksi yang ditulis siswa pada puisi, sebagai

$$
\begin{gathered}
\text { Ayah.... } \\
\text { Kau adalah pahlawan tak bersenjata } \\
\text { kau memang bukan pahlawan bangsa } \\
\text { kau juga tak iteut berjuang } \\
\text { memerdekakan indonesia.... } \\
\text { Namun... } \\
\text { kau yang bekerja keras demi dirike } \\
\text { engleaulah pahlawan yang memperuangran hidupke } \\
\text { Ayah.... } \\
\text { Pahlawan revolusi bukanlah gelar untukmu } \\
\text { Tapi... } \\
\text { Kaulah pahlawan revolusi untuk masa depanicu }
\end{gathered}
$$

Gambar 2. Diksi pada puisi

Pada lembar tes menulis puisi. Siswa membuat diksi yang menggambarkan rasa hormatnya kepada sosok ayah dan menunjukkan perasaan yang mendalam karena menggunakan kata-kata yang mampu menyentuh hati terhadap orang yang membaca dan mendengarkan puisi ini. Siswa mampu membuat diksi dengan baik dan benar. Siswa menulis puisi dengan menggunakan diksi yang sederhana namun tetap memiliki makna yang dalam. Peneliti melakukan wawancara dengan siswa, mengapa dia menulis diksi seperti itu, kemudian dia menjawab bahwa kata-kata itu menggungkapakan ketulusan hati dan rasa hormatnya terhadap ayahnya. Hal ini dapat dilihat dari hasil wawancara berikut.

P : "Kamu tahu apa yang dimaksud diksi?"

S2 : "Iya saya tahu"

$\mathrm{P} \quad$ : apakah kamu tahu makna dari kata-kata yang kamu tulis?

S2 : "Iya Bu saya tahu"

P : :Mengapa kamu menulis diksi seperti itu?"

S2 : "Karena saya sangat menghormati ayah saya yang selalu berjuang demi aku dan keluarga ku."

Struktur puisi yang ketiga adalah rima. Rima pada puisi yang ditulis siswa dapat dilihat pada gambar berikut. 


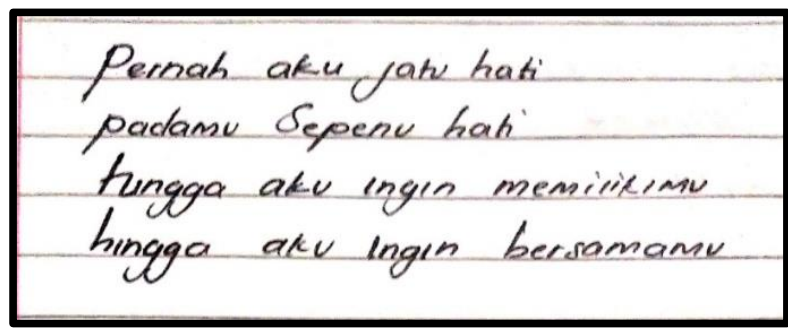

Gambar 3. Rima pada puisi

Pada lembar tes menulis puisi. Siswa membuat rima yang bersajak aa-bb. Ketika peneliti bertanya pada siswa, mengapa dia menulis rima seperti ini. Dia menjawab bahwa dengan membuat rima yang bersajak aa-bb lebih mudah dan terkesan lebih rapi. Hal ini dapat dilihat dari hasil wawancara berikut ini.

P : :Apa kamu tahu apa yang dimaksud dengan rima?"

S3 : "Iya saya tahu, Bu"

$\mathrm{P} \quad$ : "Mengapa kamu menulis rima yang bersajak aa-bb

S3 : : "Lebih mudah membuat rima yang bersajak aa-bb Bu dan kelihatan lebih rapi

Struktur puisi yang keempat adalah tipografi. Tipografi pada puisi yang ditulis siswa dapat dilihat pada gambar berikut.

Tentang setitik alr hujan
Segumpal awan hitam mulai tampak
Langit beriap untuk menangis
Dia mengeluarkan semua kelun kesannya
Yang terurai bersama titikan air hujan
Arr yang suci seperti embun
Arr yany berani seperti arr terjun
Bersama angindra jatuh kemuka bumi
Dlifingi daun-daun yg berjatuhan manja
Kuratapi setiap air yang jatuh
Kunikmati setiap hembusan anginya
Beriamanya afu meratapi kehidupan
Dandarinya afu belajar tentang sebuah kesalahan

Gambar 4. Tipografi pada puisi

Pada lembar tes menulis puisi. Siswa menulis tipografi dengan bentuk sebagian baitnya menjorok kedalam. Berdasarkan lembar tes yang telah ditulis oleh siswa, kita bisa mengetahui bahwa siswa mampu membuat tipografi sesuai indikator menulis puisi. Saat peneliti bertanya, mengapa dia menulis seperti itu. Dia menjelaskan bahwa dia terinspirasi dari contoh tayang video yang kemarin ditayangkan, menurutnya menulis puisi dengan bentuk sebagian baitnya menjorok kedalam akan terlihat lebih menarik dan bagus. Hal ini dapat dilihat pada kutipan wawancara berikut.

P : "Apa kamu paham yang dimaksud dengan tipografi?"

S4 : :Iya Bu, saya paham

$\mathrm{P} \quad$ : "Kenapa kamu menulis tipografi dengan bentuk sebagian baitnya menjorok kedalam?" 


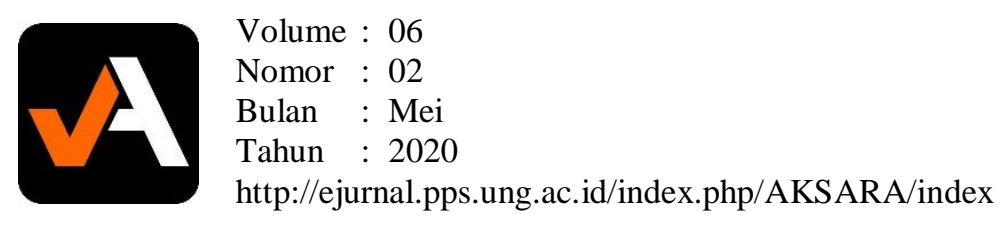

S4 : "Saya terinspirasi dari tayang video yang kemarin ibu tampilkan. Menurut saya puisi yang ditulis dengan sebagian baitnya menjorok kedalam membuat tampilan puisinya lebih menarik $\mathrm{Bu}$. Kalau hanya dibuat lurus biasa terlalu biasa saja $\mathrm{Bu}$, tapi kalau dibuat sebagian baitnya menjorok kedalam terlihat lebih bagus Bu"

Struktur puisi yang kelima adalah amanat. Amanat yang ditulis siswa dapat dilihat pada gambar berikut.

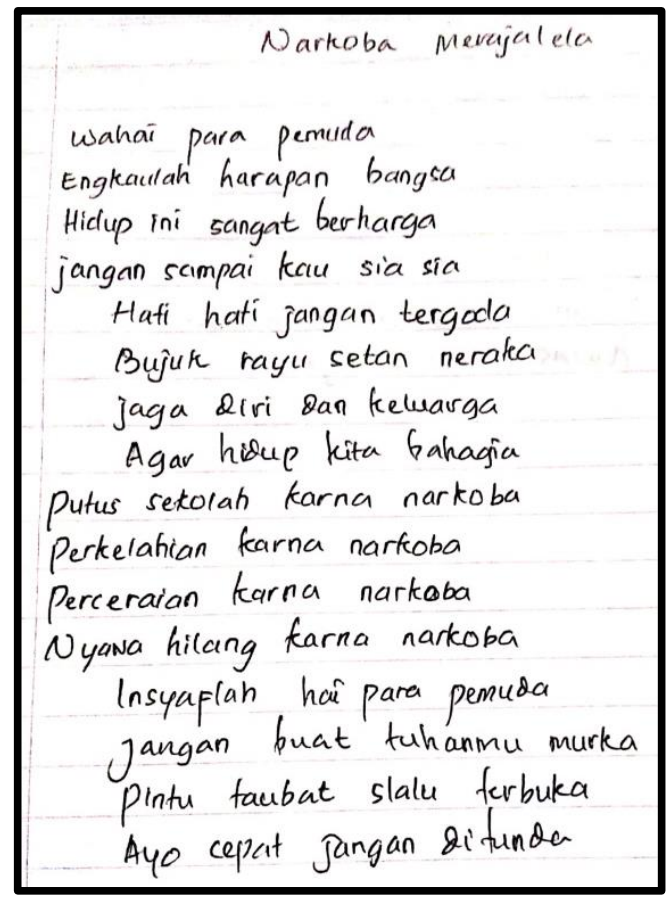

Gambar 6. Amanat pada puisi

Pada lembar tes menulis puisi siswa. Amanat yang tersampaikan dalam puisi yang berjudul "Narkoba Merajalela" sangat bermakna karena menyadarkan kita akan bahanyanya mengonsumsi narkoba. Ketika peneliti mewawancarai siswa, mengapa dia menulis puisi tentang itu. Dia menjawab bahwa dia terinspirasi dari sosialisasi yang diberikan bapak-bapak polisi mengenai remaja zaman sekarang yang terjerus dengan narkoba. Hal ini dapat dilihat dari wawancara berikut.

P : :Kenapa kamu menulis puisi tentang narkoba?"

S5 : "Waktu kemarin di sekolahkan ada sosialisasi dari bapak-bapak polisi mengenai remaja sekarang yang terjerus dengan narkoba Bu. Oleh sebab itu, saya jadi terinspirasi untuk membuat puisi tentang narkoba Bu"

\section{Pembahasan}

Merujuk pada struktur menulis puisi yang dikemukakan oleh Waluyo. Struktur puisi yang ditulis oleh siswa kelas X 2 Agama MA ABU DARRIN Kendal Bojonegoro, Indonesia sudah mengacu pada struktur puisi sesuai dengan teori Waluyo dengan benar.

Pada bagian tema puisi. Siswa menulis tema berdasarkan kisah hidupnya yang ditinggal oleh ayahnya ketika ia masih duduk dibangku kelas 2 SD. Tema merupakan ide pokok seorang penyair yang tentang kehidupan penyair yang dituangkan kedalam bentuk puisi yang memiliki makna tersirat atau tersurat (Hidayatullah, 2018). Hasil penelitian yang 
dilakukan oleh Hidayat, Rustono, dan Bakhraeni (2016) menunjukkan bahwa puisi yang dibuat oleh siswa sudah sesuai dengan teori dan karakteristik puisi anak yang dapat dilihat dari diksi atau pilihan kata yang digunakan sederhana namun tetap memiliki makna yang dalam. Tema yang ditulis siswa sudah sesuai antara judul dan isinya, puisi yang ditulis siswa memiliki rasa kekaguman terhadap guru, dan memiliki amanat yang berupa nasihat-nasihat.

Pada bagian diksi puisi. Siswa mampu menulis diksi dengan baik. Siswa menulis puisi dengan menggunakan diksi yang sederhana namun tetap memiliki makna yang dalam. Diksi yang ditulis oleh siswa menggungkapkan tentang ketulusan hati dan rasa hormatnya terhadap ayahnya yang selalu berjuang untuk dirinya dan keluarga. Diksi yaitu pilihan kata dalam mengungkapkan sebuah puisi kedalam bentuk tulisan yang penuh dengan makna (Ariyanto dan Nuryatin, 2017). Hasil penelitian yang dilakukan oleh Wilianti, Mursalim, dan Arifin (2018) menunjukkan bahwa diksi yang ditulis oleh siswa menggunakan bahasa yang sederhana sehingga mudah untuk dipahami oleh pembaca atau pendengar.

Pada bagian rima puisi. Siswa menulis puisi dengan rima yang bersajak aa-bb. Siswa lebih menyukai membuat puisi yang bersajak aa-bb karena menurutnya lebih mudah dan terlihat lebih rapi. Rima merupakan pengulangan pada bunyi yang terdapat dalam lirik atau terdapat pada akhir lirik dalam puisi (Samsuddin, 2019). Hasil penelitian Wirawan (2016) menunjukkan bahwa rima pada puisi yang berjudul "khatijah dalam balada bulan malam" memiliki rima yang bersajak aa-bb.

Pada bagian tipografi puisi. Siswa membuat puisi dengan bentuk tipografi yang sebagian baitnya mencorok kedalam. Berdasarkan tayangan video yang sebelumnya ditampilkan oleh peneliti, siswa terinspirasi untuk membuat puisi yang sebagian baitnya menjorok kedalam, menurutnya menulis puisi dengan bentuk sebagian baitnya menjorok kedalam akan terlihat lebih menarik dan bagus. Tipografi merupakan tatanan dalam menyusun baris dan bait puisi yang tersusun hingga membentuk sebuah puisi. Tipografi memiliki beragam bentuk yaitu berbentuk segitiga, bundar, kerucut, sebagian baitnya menjorok kedalam, dan lain-lain (Juhara, Budiman, dan Rohayati 2005). Hasil penelitian yang dilakukan oleh Sitohang (2018) menunjukkan bahwa tipografi pada puisi "penerimaan" karya chairil anwar terdiri enam bait puisi dan penulisan disetiap barisnya menggunakan huruf besar atau kapital.

Pada bagian amanat puisi. Siswa menulis puisi dengan judul "Narkoba Merajalela" memiliki makna yang dalam karena menyadarkan kita akan bahannya mengonsumsi narkoba. Siswa terinspirasi dari sosialisasi yang diberikan bapak-bapak polisi mengenai remaja zaman sekarang yang terjerus dengan narkoba. Oleh sebab itu siswa tersebut terinspirasi untuk membuat sebuah puisi yang bertemakan tentang narkoba. Menurut Surastina (2018) amanat merupakan pesan yang ingin disampaikan oleh penyair kepada pembaca yang berisi pesan moral didalamnya. Hasil penelitian Fransori (2017) menunjukkan bahwa puisi chairil Anwar yang berjudul kepada peminta-minta terdapat amanat dan pesan moral yang disampaikan.

Hasil penelitian Saddhono, Hasanudin, dan Fitrianingsih (2019) dengan menerapkan strategi SSCS menunjukkan hasil bahwa pada tingkat kemampuan berpikir kreatif level 4, mahasiswa sangat kreatif dalam menemukan frasa dan menyusunnya menjadi suatu kalimat majemuk.

\section{Simpulan}

Puisi yang ditulis oleh siswa kelas X 2 Agama MA ABUDARRIN Kendal Bojonegoro, Indonesia pada pembelajaran dengan menerapkan metode SSCS dan media 


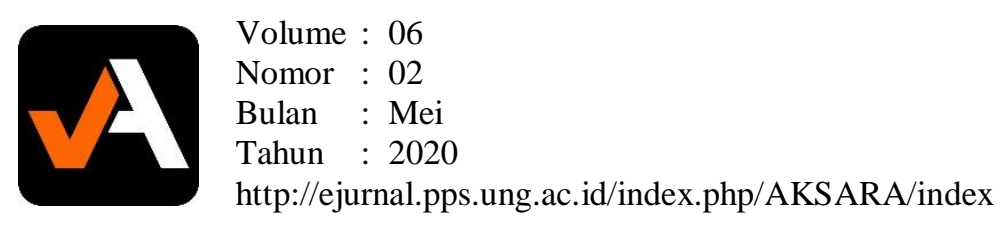

audio visual telah mengacu pada struktur puisi sesuai dengan teori Waluyo dengan baik. Pada bagian tema, siswa menulis tema berdasarkan kisah hidupnya yang ditinggal oleh ayahnya ketika ia masih duduk dibangku kelas 2 SD. Diksi yang ditulis oleh siswa menggungkapkan tentang ketulusan hati dan rasa hormatnya terhadap ayahnya yang selalu berjuang untuk dirinya dan keluarga. Rima yang ditulis siswa bersajak aa-bb. Tipografi yang ditulis siswa berbentuk sebagian baitnya menjorok kedalam. Pada bagian amanat siswa menulis puisi dengan judul "Narkoba Merajalela" memiliki makna yang dalam karena menyadarkan kita akan bahannya mengonsumsi narkoba. Berdasarkan puisi yang telah ditulis oleh siswa, bisa dikatakan bahwa metode SSCS dan audio visual sangat tepat diterapkan pada pembelajaran.

\section{Daftar Pustaka}

Agustin, S., Fitraini, D., Rahmi, D., \& Fitri, I. (2018). Pengaruh model pembelajaran search, solve, create, and share (sscs) terhadap pemahaman konsep matematis ditinjau dari pengetahuan awal siswa. Jurnal cendikia, 2(2), 42-53. Retrieved from https://j-cup.org/index.php /cendekia /article / view/1

Arikunto, S. (2006). Prosedur penelitian suatu pendekatan praktik. Jakarta: Rineka cipta.

Ariyanto, D \& Nuryatin, A. (2017). Badik dalam "mata badik mata" puisi karya D. Zawawi Imron:perspektif paul ricoeur. Seloka, 6(2), 161-168. Retrieved from https://journal.unnes.ac.id/sju/index.php/seloka/article/view/17281

Astuti, N. P. E. F., Suweken, G., \& Waluyo, D. (2018). Pengaruh model pembelajaran search, solve, create, and share (sscs) terhadap pemahaman konsep matematika siswa kelas VIII SMP Negeri I Banjar. Jurnal pendidikan matematika undiksha, 9(2), 84-95. Retrieved from https://ejournal.undiksha.ac.id/index.php/JJPM/article/viewFile/19901/12158

Deli, M. (2015). Penerapan model pembelajaran search, solve, create, and share (SSCS) untuk meningkatakan motivasi belajar matematika siswa kelas VII-2 SMP Negeri 13 Pekanbaru. Jurnal Primary, 4 (1), 71-78. Retrieved from https://www.neliti.com/publications/258300/penerapan-model-pembelajaransearch-solve-create-share-sscs-untuk-meningkatkan-m

Fransori, A. (2017). Analisis stilistika pada puisi kepada peminta-minta karya chairil anwar. Deiksis, 9(1), 1-12. Retrieved from https://journal.lppmunindra.ac.id/index.php/Deiksis/article/view/884

Hasanudin, C. (2017). Media pembelajaran: Kajian teoritis dan kemanfaatan. Yogyakarta: Deepublish Publisher.

Hatari, N., Widiyatmoko, A., \& Parmin. (2016). Keefektifan model pembelajaran search, solve, create, and share (SSCS) terhadap keterampilan berpikir kritis siswa. Unnes science education journal, 5 (2), 1253-1260. Retrieved from https://journal.unnes.ac.id/sju/index.php/usej/article/view/13144

Hermawan, I. J. (2017). Peningkatan kemampuan menulis puisi dengan menggunakan media audio visual. Jurnal diksatrasia, 1(1), 39-45. Retrieved from https://jurnal.unigal.ac.id/index.php/diksatrasia/article / view/183

Hernawati, E. (2018). Meningkatkan hasil belajar fisika melalui penggunaan metode demonstrasi dan media audiovisual pada siswa kelas X MAN 4 Jakarta. Andragogi jurnal diklat teknis, 6(2), 118-131. Retrieved from https://pusdiklattekniskemenag.e-journal.id/andragogi/article/view/60 
Hidayah, N. H., Darmuki, A., \& Hasanudin, C. (2019). Peningkatan keterampilan menulis puisi dengan menggunkana metode quantum learning dan media video pada siswa kelas x IPA I SMA Negeri 2 Blora tahun ajaran 2018/2019. Jurnalistrendi, 4 (1), 309-320. Retrieved from http://ejournal.unwmataram.ac.id/trendi/article/view/152

Hidayat, C. A., Rustono., \& Bakhraeni, R. (2016). Analisis unsur intrinsik puisi tema guru karya siswa kelas V SDN 1 Nagarasari. Pedadidaktika, 3(1), 24-32. Retrieved from https://ejournal.upi.edu/index.php/pedadidaktika/article/view/4766

Hidayatullah, A. (2018). Tema dan gaya bahasa puisi siswa SMP: kajian struktural. Journal of language learning, 2(2), 1-11. Retrieved from https://journal.uhamka.ac.id/index.php/jollar/article/view/3475

Juhara, E., Budiman, E., \& Rohayati, R. (2005). Cendikia berbahasa. Jakarta Selatan: PT setia purna inves.

Julaeha, S. (2018). Penerapan metode field trip untuk meningkatkan hasil belajar peserta didik pada mata pelajaran bahasa Indonesia materi menulis puisi. Jurnal penelitian, 1(2), 310-323. Retrieved from http://ejournal.unsub.ac.id/index.php/JPG/article/download/355/326

Kibtiyah, A. M. \& Abbas, N. (2014). Peningkatan keterampilan menulis piuisi bebas melalui metode sugesti-imajinasi dengan media lagu. Joyful learning journal, 3(1), 61-65.

Retrieved

from https://journal.unnes.ac.id/sju/index.php/jlj/article/view/5899

Laeli, A. N., Wagiran., \& Suseno. (2014). Peningkatan keterampilan menulis puisi keindahan alam menggunakan metode partisipatori dengan media gambar. Jurnal pendidikan bahasa dan sastra Indonesia, 3(1), 1-7. Retrieved from https://journal.unnes.ac.id/sju/index.php/jpbsi/article/view/3989

Mamik. (2014). Metodologi kualitatif. Sidoarjo: Zifatama.

Maulana, A., Wancik, K. A., \& Sofia. (2014). Penerapan model pembelajaran Search, Solve, Create, and Share (SSCS) untuk meningkatkan hasil belajar siswa dikelas XI IPA SMA. Jurnal penelitian pendidikan kimia, 1(1), 9-17. Retrieved from https://ejournal.unsri.ac.id/ index.php/jurpenkim /arti cle/view/2227

Moleong, L. J. (2015). Metodologi penelitian kualitatif. Bandung: PT remaja rosdakarya. Nurfaedah. (2019). Keefektifan media audio visual dalam meningkatankan kompetensi siswa sekolah menengah pertama dalam menulis puisi. Indonesian journal of instructional media and model, 1(1), 26-34. Retrieved from http://journal.univetbantara. ac.id/index.php/ijimm/article /view/316

Periartawan, E., Japa. \& Widiana, W. (2014). Pengaruh model pembelajaran SSCS terhadap kemampuan pemecahan masalah matematika siswa kelas IV di gugus XV Kalibukbuk. Journal mimbar PGSD, 2(1), 1-10. Retrieved from https://ejournal.undiksha.ac.id/index.php/JJPGSD/article/view/2045

Putri, W. L. \& Widihastrini, F. (2014). Peningkatan keterampilan menulis puisi melalui metode mind mapping dengan media audiovisual. Joyful learning journal, 3(2), 816. Retrieved from https://journal.unnes.ac.id/sju/ index . php/jlj/article/view/5901 Rahmawati, N. T., \& Sugianto. (2016). Analisis kemampuan berpikir kreatif matematik ditinjau dari kesadaran metakognisi siswa pada pembelajaran SSCS berbantuan schoology. Unnes journal of mathematics education research, 5(1), 24-31. Retrieved from https://journal.unnes.ac.id/sju/index .php/ujmer/article/view/12913 
Rahmawati, N. T., Junaedi, I., \& Kurniasih, A. W. (2013). Keefektifan model pembelajaran SSCS berbantukan kartu masalah terhadap kemampuan pemecahan masalah siswa. Unnes journal of mathematics education, 2(3), 66-71. Retrieved from https://journal.unnes.ac.id/ sju/index.php /ujme/ article /view/3447

Retnowati, R., Suharyati, H., Manurung, R.T., Maknun, D., Armariena, D.N., Hetilaniar, H., Hasanudin, C., Murniviyanti, L., Anwar, S., Setyorini, R. (2018). The effect of environmental teaching method and the level of natural intelligence on the environmental view of the students behavior. Journal of Physics: Conference Series, 1114(1): 1-7. https://doi.org/10.1088/17426596/1114/1/012104.

Rifai. (2012). Kualitatif: teori, praktek \& riset penelitian kualitatif teologi. Sukoharjo: Bornwin's publishing.

Rukin. (2019). Metodologi penelitian kualitatif. Sulawesi selatan: Yayasan ahmar cendikia Indonesia.

Saddhono, K., Hasanudin, C., \& Fitrianingsih, A. (2019). The ability to think creatively on SSCS using schoology Apps, how is the student's language metacognitive awareness? Ingénierie des Systèmes d'Information, 24(4): 367-375. https://doi.org/10.18280/isi.240402.

Samsuddin. (2019). Buku ajar pembelajaran kritik sastra. Yogyakarta: Deepublish.

Sarastini, D. D., Rasana, R., \& Sulastri, M. (2014). Pengaruh model pembelajaran sscs terhadap pemahaman konsep IPA siswa kelas V SD di gugus I kecamatan Buleleng. Jurnal Mimbar PGSD universitas pendidikan ganesha, 2(1), 1-10. Retrieved from https://ejournal.undiksha.ac.id/index.php/JJPGSD/article/view /3068

Sitohang, K. (2018). Pengkajian puisi penerimaan chairil anwar menggunakan pendekatan stilistika. Jurnal membaca, 3(1), 45-50. Retrieved from http://jurnal.untirta.ac.id/index.php/jurnalmembaca/article/view/3744

Sugiyono. (2015). Memahami penelitian kualitatif. Bandung: Alfabeta.

Sugiyono. (2015). Metode penelitian kuantitatif, kualitatif dan $r \& d$. Bandung: Alfabeta.

Suherli., Suryaman, M., Septiaji, A., \& Istiqomah. (2017). Bahasa Indonesia. Jakarta: Kementerian pendidikan dan kebudayaan.

Sulfemi, W. B. (2019). Model pembelajaran kooperatif mind mapping berbantu audio visual dalam meningkatkan minat, motivasi dan hasil belajar IPS. Jurnal pipsi, 4(1), 13-19.

Retrieved

from https://journal.stkipsingkawang.ac.id/index.php/JurnalPIPSI/article/view/1204

Surastina. (2018). Pengantar teori sastra. Yogyakarta: Elmatera.

Syarwah, R. A., Fauziddin, M., \& Hidayat, A. (2019). Peningkatan motivasi belajar siswa menggunakan media audio visual pada pembelajaran bahasa Indonesia. Jurnal pendidikan tambusai, 2(5), 936-945. Retrieved from https://jptam.org/index.php/jptam/article/view/300

Wilianti, R., Mursalim., \& Arifin, S. (2018). Analisis diksi puisi wajah negeri kita karya M. Anwar M. H. Jurnal ilmu budaya, 2(3), 286-292. Retrieved from http://ejournals.unmul.ac.id/index.php/JBSSB/article/view/1034

Wirawan, G. (2016). Analisis struktural antologi puisi hujan lolos disela jari karya yudhiswara. Jurnal pendidikan bahasa dan sastra Indonesia, 1(2), 39-44. Retrieved from https://journal.stkipsingkawang.ac.id/index.php/JP-BSI/article/view/89 